\title{
Here Comes the Flood, but Not Failure? Lessons to Learn after the Heavy Rain and Pluvial Floods in Germany 2021
}

\author{
Alexander Fekete ${ }^{1, *(1)}$ and Simone Sandholz ${ }^{2}(\mathbb{D}$ \\ 1 Institute of Rescue Engineering and Civil Protection, TH Köln-University of Applied Sciences, \\ 50678 Köln, Germany \\ 2 Institute for Environment and Human Security, United Nations University (UNU-EHS), \\ 53113 Bonn, Germany; sandholz@ehs.unu.edu \\ * Correspondence: alexander.fekete@th-koeln.de; Tel.: +49-(0)221-8275-2604
}

check for updates

Citation: Fekete, A.; Sandholz, S. Here Comes the Flood, but Not Failure? Lessons to Learn after the Heavy Rain and Pluvial Floods in Germany 2021. Water 2021, 13, 3016. https://doi.org/10.3390/w13213016

Academic Editors: Eric Duviella and Pablo Segovia

Received: 14 September 2021

Accepted: 25 October 2021

Published: 27 October 2021

Publisher's Note: MDPI stays neutral with regard to jurisdictional claims in published maps and institutional affiliations.

Copyright: (c) 2021 by the authors. Licensee MDPI, Basel, Switzerland. This article is an open access article distributed under the terms and conditions of the Creative Commons Attribution (CC BY) license (https:// creativecommons.org/licenses/by/ $4.0 /)$.

\begin{abstract}
Floods are a known natural hazard in Germany, but the amount of precipitation and ensuing high death toll and damages after the events especially from 14 to 15 July 2021 came as a surprise. Almost immediately questions about failure in the early warning chains and the effectiveness of the German response emerged, also internationally. This article presents lessons to learn and argues against a blame culture. The findings are based on comparisons with findings from previous research projects carried out in the Rhein-Erft Kreis and the city of Cologne, as well as on discussions with operational relief forces after the 2021 events. The main disaster aspects of the 2021 flood are related to issuing and understanding warnings, a lack of information and data exchange, unfolding upon a situation of an ongoing pandemic and aggravated further by critical infrastructure failure. Increasing frequencies of flash floods and other extremes due to climate change are just one side of the transformation and challenge, Germany and neighbouring countries are facing. The vulnerability paradox also heavily contributes to it; German society became increasingly vulnerable to failure due to an increased dependency on its infrastructure and emergency system, and the ensuing expectations of the public for a perfect system.
\end{abstract}

Keywords: flash flood; cascading impacts; compounding event; multi-risk; disaster risk management; Germany

\section{Introduction}

The floods in July 2021 have caught many by surprise in Germany; people affected, authorities, the private sector, media and the media-informed general population. A protection system that thrives on its individual parts interlocking reached and exceeded its limits. It does not help to point out that disasters are the epitome of surprise; researchers alike felt amazed or even frustrated about the losses despite years or decades of research. Scientific research hence also needs to analyse in the months following, which lessons are to learn, for science as much as for policy, governance or everyday person, being affected or not. At this early stage, some observations can be made and shared to inspire a broader and more thorough investigation to follow, in Germany and neighbouring countries.

From 14 to 15 July 2021, more than 180 lives were claimed by floods caused by heavy rain in Germany [1], and more than 40,000 people were affected [2]. Two Bundesländer (Federal States) were affected mainly; North-Rhine Westphalia and adjacent RhinelandPalatinate, but other States were affected, too. A slow-moving large summer storm system named 'Bernd', attributed in size and moisture to climate change, led to high amounts of rain (up to $150 \mathrm{~mm}$ within $48 \mathrm{~h}$, (see also Figure 1) and respective river discharge peak flows $[1,3,4]$. Neighbouring countries such as Belgium (more than 30 casualties), Luxembourg and France also experienced heavy rain due to the same storm system. Other areas in Europe and worldwide, also saw heavy rain and floods damages in the summer 
of 2021, such as Afghanistan, Austria, China, Croatia, Czech Republic, India, Italy, New Zealand, Pakistan, Romania, Switzerland, Turkey, UK, USA.

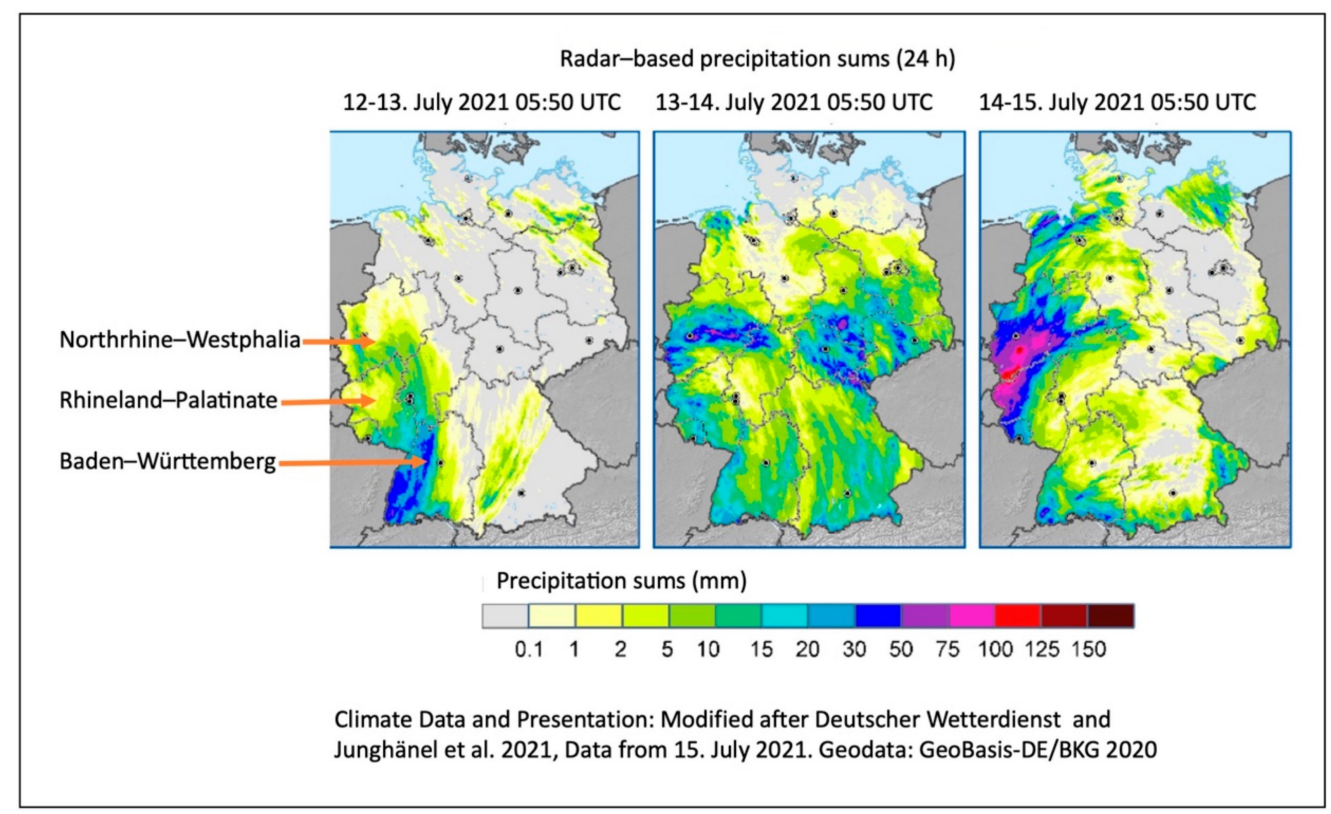

Figure 1. Precipitation data from 12 to 15 July 2021 in Germany, modified from [4].

It appears to be a summer of extreme events that also saw the opposite of too much water; droughts and wildfires. This early report restricts itself to floods and the events in Germany, and specific aspects of this wider topic, that fall into the expertise and scope of the authors. It starts from reflecting upon specific aspects of risk and resilience assessment and planning on critical infrastructure $(\mathrm{CI})$, which have been the main content of a 3-years project 2016-2019 in one of the affected areas, in Rhein-Erft Kreis and Cologne, the CIRmin project on 'Critical Infrastructures Resilience as a Minimum Supply Concept' [5-7]. However, the article also covers pertinent aspects of social vulnerability, civil protection, disaster preparedness, operational disaster management, communication and perception, spatial assessments, as this also is of relevance to inform further lessons to learn. Some interdisciplinary findings of the implications of this event for the future planning of communities and cities already have been published after this event $[8,9]$.

This paper aims to address the subject holistically, even when it must be acknowledged that not all the important aspects can be covered in this early report. It is a snapshot while the processing is still in progress, which helps to come to terms with the experiences of the early relief and recovery phase. The analysis of the recent flood event is based on media and news reviews as well as own observations and data collection of the authors. We have carried out an online survey with operational response forces and voluntary helpers $(\mathrm{N}=2264)$, focus group discussions, interviews and field visits with crisis managers, flood experts, local and Federal administration and affected people, that all help to inform this paper. The online survey is structured into 20 questions on motivational aspects and 11 questions about the respondents and their background. From these, 9 questions are directly based on a previous survey we had conducted after the floods in 2013 [10] to enable a comparison. The questions are organised as 24 closed questions and 7 open-ended questions. The questions were developed within focus group discussions with flood responders. Pretests were run with 60 persons, including 20 foreign experts. The survey ran from 1 to 21 September 2021 and was carried out with the online tool SoSciSurvey. Participation in the survey was voluntary. The survey was viewed 5986 times and 2571 questionnaires were completed. After data cleaning, a sample of 2264 remained. The open-answer text fields were used by 911 respondents and 37,400 words of text were collected. Of the respondents, $12 \%$ participated in the operations as spontaneous volunteers, the others in different ranks 
within their organisations and $8 \%$ of them were from professional organisations. Another $8 \%$ were affected by the flood themselves but helped in the operations.

\section{Replay of July Flood Events: Losses, Damages, Responses and Perceptions}

The overall situation unfolded much in the timeline of phases often observed as typical in disasters [11] (Figure 2). Raphael based her timeline graph on findings after the Buffalo Creek Flood [12]. This timeline is conceptual, for explanatory purposes of the typical phases of a flood. Early on, it was recognised that the adaptational response (y-axis in Figure 2) fluctuates, with a beginning increase in motivation and resources allocated, followed by a decline. This decline can sometimes even result in a more negative motivation and factual response than before the flood happened. This conceptual depiction was found to fit very well with the situation that unfolded in the floods in 2021 in Germany.

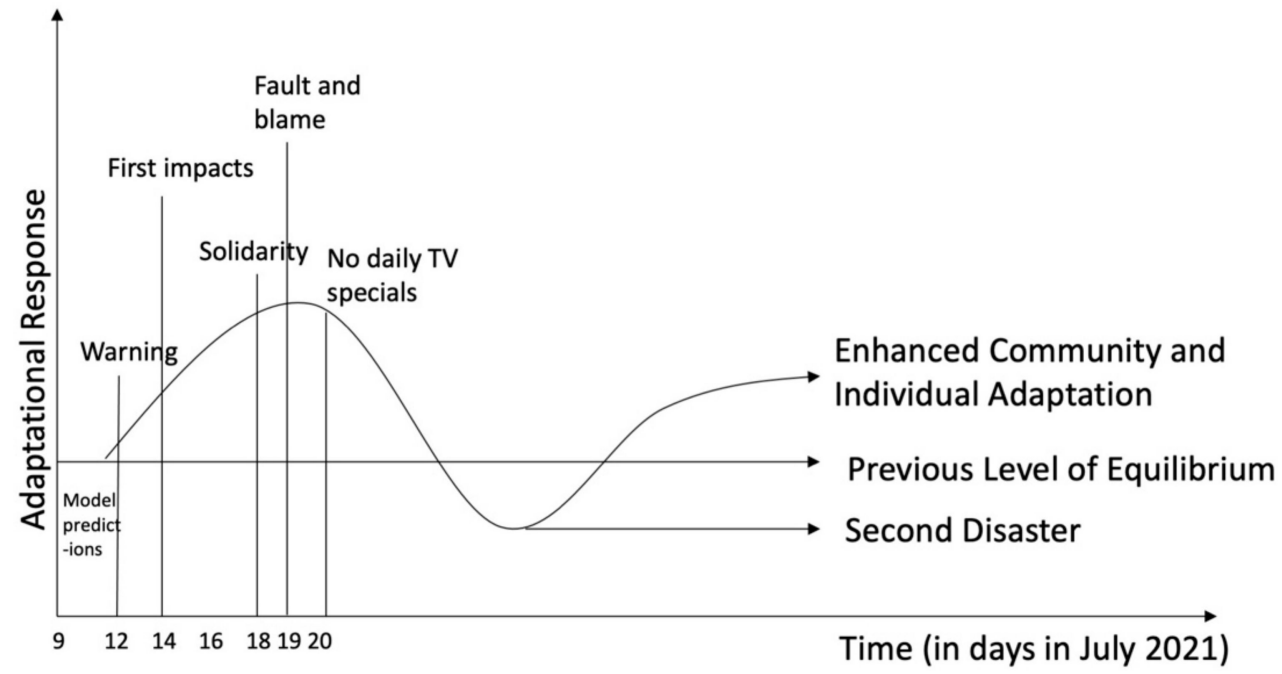

Figure 2. Time-phase of awareness and response to the 2021 flood in Germany, based on Raphael 1986, Erikson 1976.

Impacts such as buildings flooded and people drowning started in different regions in Germany from 14 July. The warning, quite a contested issue [13], started with model predictions at the European system EFAS on 9 to 12 July [14], and the German weather broadcasting agency started issuing weather warnings on 12 July [15], information on social media apps of national agencies and private providers followed. Within a warning chain distributed among the responsibilities of Bundesländer and local communities, warnings were issued locally by the respective authorities, but heterogeneously, depending on the timing of the warning, the sources and some corrections [16]. Whether the warning communication has been carried out in all respects as laid down in official protocols and by the district administrators is still under legal investigation by enquiry commissions [17-19]. However, there were initial critical voices, among others from the scientific community [20]. The controversy about the warnings led to a public discussion, also on national media, that was observable to start 14/15 July, had a peak in national TV coverage between 16 and 20 July, with almost daily TV specials in the major official TV channels, ARD- and its regional stations-, the ZDF and others. Solidarity was a major topic and perceived at national level TV and newspapers from at least 18 July, onwards [21]. Fault and blame questions regarding the warnings became prominent on 19 July and following. 6 August, the first legal investigations were announced to clarify failures in the warning chains for certain localities [17]. At the beginning of September, after pressure from within their own fraction, the administrator of one of the most heavily affected districts (Ahrweiler county) announced that he wanted to retire early, officially due to health reasons [22].

Relief operations were carried out by local and regional, even German-wide organisations of civil protection, that includes fire brigades, paramedics, the Technical Relief Agency 
(THW) and many others. The response operations were conducted under the protocols and established processes of the emergency and disaster management. Volunteered help by neighbours, farmers using heavy machinery, forest workers, NGOs and many more started in parallel.

Losses and damages surmount to over 180 lives claimed, mostly residents, but also operational forces [18], in Germany alone. Insurance losses add up to more than $€ 7$ billion, out of which around $€ 6.5$ billion on residential buildings, household goods and businesses, and around $€ 450$ million on motor vehicles [23]. Federal and state governments have agreed on a flood relief fund with a volume of $€ 30$ billion to support reconstruction [24]. Infrastructure damage is a major topic since almost all bridges in the Ahr valley were destroyed, also sections of national highways, major access routes to affected sites, gas, water, electricity, and other supply infrastructure [3]. Around 65 hospitals, 63 drug stores, 48 care homes, 200 doctors' offices [20], $600 \mathrm{~km}$ of railway, 50 railway bridges were damaged [25], just as another example. Going into detail will require more studies and time.

\section{Conceptual Findings on Risk Knowledge and Communication Aspects}

From the breadth of topics, we have selected communication and knowledge exchange around topics of disaster risk related to infrastructure, since they represent a core theme in the flood disaster 2021 collective debates. Communication is connected to technical means of infrastructure, but it is more than that; it is mainly about people and their interaction with information and with other people about it. Just as well, the topic of critical infrastructure (CI) is not about the physical objects only, it is a system that comprises humans, the environment and also non-visible aspects, too. The following four sub-sections detail these for four key areas; knowledge interpretation and communication gaps; data and data exchange gaps between actors; decoding compounding events and escalations in social cohesion; and, compounding escalations due to $\mathrm{CI}$ failure. These four areas are connected because the main disaster aspects of the $2021 \mathrm{flood}$ are related to issuing and understanding warnings, a lack of information and data exchange, unfolding upon a situation of an ongoing pandemic and aggravated further by $\mathrm{CI}$ failure.

\subsection{Knowledge Interpretation and Communication Gaps}

The 2021 floods once more have revealed how important decoding communication problems in early warnings is. The results of our online survey reveal that missing information is the top problem reported by $51 \%$ of the respondents, but also misinformation by official sources (32\% or from the media (27\%) [26]. The details in the open replies reveal that misinformation was a problem caused by protest groups hindering the operations, or misinformation concerning coordination. Missing information was seen as a problem by $39.8 \%$. We have compared this to our survey after the 2013 floods where missing information was perceived as a problem by only $20 \%$ [10]. Information supply was regarded as very poor by $16.6 \%$ before the operation and by $14.7 \%$ during the operation in 2021 . In 2013 , it was a similar tendency; $7 \%$ regarded information supply as very poor before, and $6 \%$ during the operation.

Another related area is a demand for improvements in coordination by $55 \%$ of the respondents, and exchange between organisations by $53 \%$. Information of the population is mentioned by $52 \%$ as an area of necessary improvement. This corresponds to results of a household survey done in the CIRMin project, where more than $57 \%$ of the respondents stated that they had never received information around individual disaster preparedness and private precaution and stockpiling for outages of critical infrastructures [27]. Notably, such information on precautionary measures was and is available from public authorities like the Federal Office of Civil Protection and Disaster Relief (BBK), raising questions around perceived availability of information, access to it and target-group specific communication.

Questions of blame and guilt dominated public attention after the flood [15-17], but the question of how to do it better next time should be even more important. Therefore, it 
may be helpful to decipher how different people interpret the same information differently rather than blaming anyone. Starting with an analysis, going back to theories of semiotics can help to break down communication about the flood (Figure 3). At problem level 1, it is a matter of interpretation of floods and related means of warning. In semiotics, the process of interpretation is a semiosis, which means that interpretations are an ongoing process and change constantly [28-30]. During the ongoing flood, interpretations changed for example by local residents depending on the information they received. What also changed was the flood itself that rose at unexpected speeds, but also the warnings that came in changed [16] Some information was observed directly on-site, but a large share of information came in indirectly; someone talking about the river rising, information on the mobile phones, as long as they lasted etc. Semiotics differentiates between real objects and the language and signs by which humans communicate about them. While observations about objects and incoming signs already differ, the consciousness generated by interpreting those objects and signs is memorised in the minds, and also constantly changes [29]. This helps to understand why the one and same person can experience changing perceptions about the same event or information about it. For example, people often need confirmation about a warning or a repetition of a warning to trust it [31]. It also helps to explain, why actions are not taken the same way, based on the same information (problem level 2, Figure 3). Moreover, it explains why the combination of interpretation changes and resulting actions that also are non-constant, increase the challenges of communicating with other people about the same flood event (problem level 3).

Decoding Disaster Communication

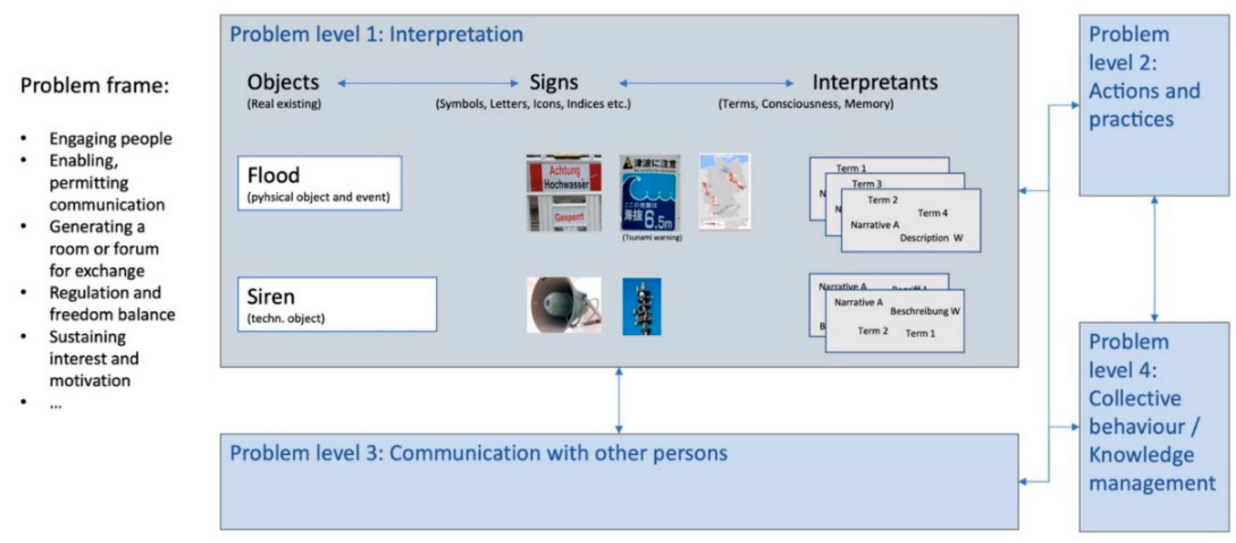

Figure 3. Decoding transfer of knowledge problems in flood warnings.

This already should provide a strong warning not to blame individuals acting differently upon the same event. It is also a warning not to rely on snapshots, but to monitor perceptions by different groups over time, from the disaster occurrence, its immediate aftermaths to the long-term recovery. Certainly, this needs to be embedded into a broader context, too, of a public audience becoming involved by such extraordinary flood events (problem level 4). The question of how and what is perceived collectively reaches another dimension, but again is based on the same principles of having to decode what is discussed based on observations about the objects and their changes over time. In this case, the flood itself, and the other objects such as sirens involved, the signs and means of language used to report and discuss it (and their restrictions) and the interpretants (the different codes in our minds). Furthermore, the overall framing in a community or society in addition has a great impact, how and whether people engage in such a discussion or not. The flood 2021 confirmed standard aspects of community resilience or a nation's resilience, such as engagement or access to information [32]. The topics typical for Germany became evident; in particular a frame of strong regulation, and the debate of its shortcomings.

The following observations are based on insights into the CIRmin research project, which was carried out by several institutions from administration, infrastructure operators 
and academic institutions from 2016-2019 in the county Rhein-Erft Kreis, city of Cologne and city of Mülheim an der Ruhr [33]. The main target was the development of a baseline understanding of $\mathrm{CI}$ and a concept to foster resilience by focusing on the question of which infrastructure to prioritise and support to function as a minimum in a long-lasting and widespread crisis. In the CIRmin project, a communication gap was the starting point for this project; even while the city of Cologne and the Rhein-Erft Kreis are direct neighbours, an exchange between emergency management and CI operators had been missing so far, at least on a working level. To illustrate it along with an example that relates the findings on several CI aspects of the projects to the 2021 flood, Figure 4 sketches it in a more abstract way that is not based on the real situations in Cologne or Rhein-Erft Kreis. However, we also found this principle in other projects; while community A has a certain knowledge or technology, its neighbour, community B, may not have it. This can include many types of knowledge; knowledge about a hazard, or about preventive measures, access to information or networks, and many more forms of tacit and explicit knowledge. There are also multiple actors and connections that enable multiple ways of knowledge exchange; official bodies and networks as much as private and informal networks [5]. Knowledge exchange and communication is not a two-way process only and should occur at different times, before, during and after a disaster, for example. External actors are important to introduce new ideas, information and to enable exchange of knowledge, too. In this sense, the research project CIRmin served as a mediator, that brought together new ways and actor constellations, and guided their dialogue through a scientific method of system and interdependency analysis [5].

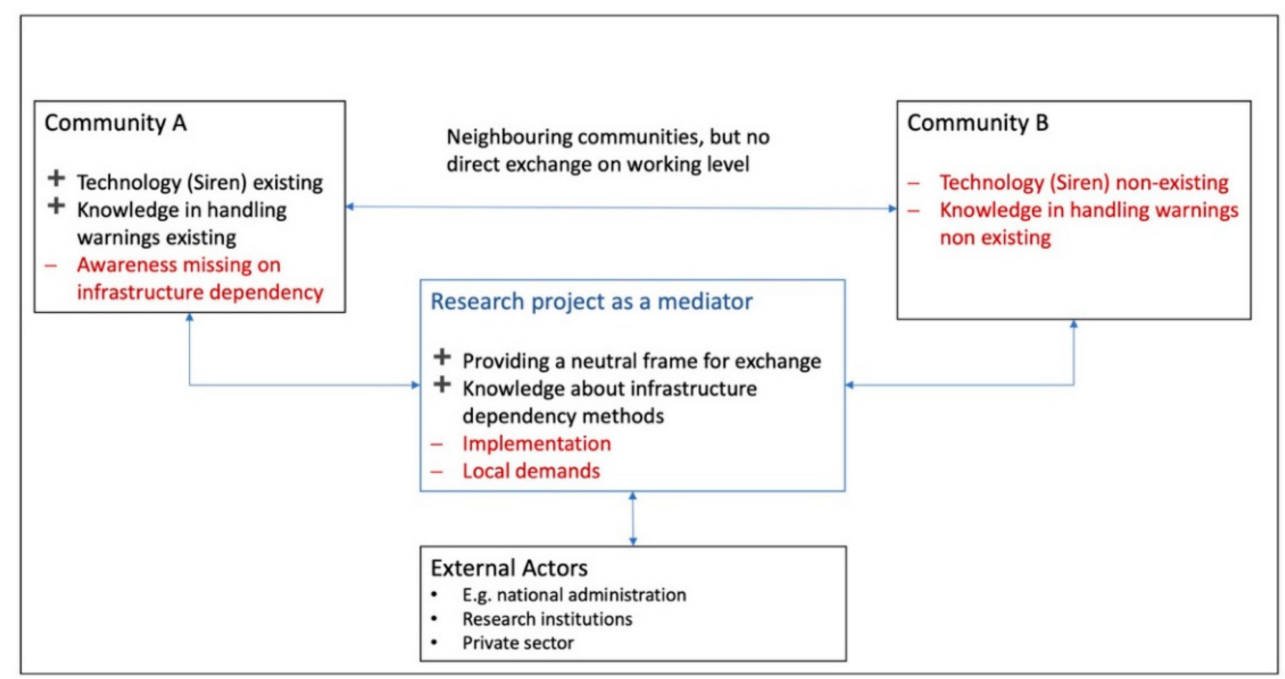

Figure 4. Schematic example of a knowledge exchange demand between neighbouring communities.

This proved to be the case not only for Rhein-Erft Kreis and Cologne, but many other communities affected in 2021 as well, as recorded during an open exchange between students and emergency managers on 4 August 2021 at the Technical University Cologne (oral.com (accessed on 4 September 2021), anonymised). Universities or research projects in this case serve as a mediator and enable dialogue between different stakeholders of different emergency organisations that do not often have such an exchange. It reveals the demand for knowledge exchange, its management and documentation, even between direct neighbours. Reasons for the demand for more dialogue are manifold, not only due to framing and lack of occasions due to a lack of recent disasters, but this is also due to different working levels, actor groups and persons changing positions, as well as perceptions and communication channels, as depicted by Figure 3 before. 


\subsection{Data and Data Exchange Gaps between Actors}

Open data access, data exchange about natural hazards and related aspects are challenges in Germany. The online survey we conducted in 2021 revealed missing information to be a constraint in the flood operations for $51 \%$ of the respondents [26]. Alerting was a problem for $38 \%$ of the respondents. After the flood events in 2002 at the rivers Elbe in the East of Germany, and the river Danube in the South, a research project tried to establish a 'Disaster information system for large-scale flood events using earth observation' (DISFLOOD) [34]. Access to flood models of hydrological models for riverine floods was a challenge, also due to many models not being developed yet at that time. But even more difficult it proved to acquire missing flood scenario maps or access to data on social vulnerabilities when asking different Bundesländer. Due to worries about autonomy, some refused to provide their data for a research project that aimed at generating flood information over Germany as a whole [35]. The European flood directive helped research and local communities a lot when Germany was forced to produce flood hazard and risk maps and accordingly, management plans, just like other European countries until 2012 [36]. But due to the ongoing conflict of autonomy between the 16 Bundesländer and the national state of Germany, even in 2021, certain data are still not openly accessible. For example, high-resolution digital elevation models are provided by a few Bundesländer only. For many Bundesländer and cities, information about vulnerable populations or demographic profiles is only available for a whole city or municipality, but not at higher resolution. This is due to data privacy laws, and this makes sense for many areas, but it severely hampers flood risk and vulnerability mapping and modelling. While some German cities have good open data platforms, and some Bundesländer, as well as the national state, have good Geo-Information portals, still, a lot of basic information is not accessible. Even if it is accessible there is no one-stop solution, but data need to be found on municipal or Bundesländer websites etc., each with its own storage system and logic.

It came as no surprise, hence, that in the CIRMin project about CI resilience at the local level, several important data were available only at coarse resolution. While Cologne, a major city in Germany with respective resources, has produced riverine, groundwater and pluvial flood maps at high resolution and openly provides it online, the neighbouring communities, with fewer resources, have no such maps. But this was not the only problem observed while conducting mapping and related analyses. The maps on riverine flood hazard extent cover a wide area of the city of Cologne, and also along the river Erft in Erftstadt [6]. Erftstadt and especially, Erftstadt-Blessem were heavily affected by the 2021 pluvial floods. Pluvial flood maps were not available publicly in 2020, only riverine hazard zones (light blue area in Figure 5). In the mapping conducted in 2020, some of the flooded areas of 2021 were covered, however (Figure 5, dark blue area marked with 'B'). The example of the dark blue area mapped is just an example, based on one non-oblique aerial photo, and not the total area. Further mapping will be conducted, when oblique aerial mapping can be obtained, to compare the predicted (light blue) and real flood extent. An important additional hazard phenomenon at this specific example is backward erosion that affected an area of $300 \mathrm{~m}$ from the gravel pit to the village and destroyed three houses. We also have observed this visiting the affected area there. This shows the importance to improve flood risk mapping to become even more micro-scale. Probably, backward erosion has to be included as a secondary hazard. Yet another aspect is relevant; on the official flood risk maps, certain road segments that had a slight elevation above ground were not designated with a flood signature (See arrow and the ' $A$ ' marked in Figure 5). In our mapping in 2020 [6], we have manually included about additional $200 \mathrm{~km}$ of such road segments [6] (Figure 5) based on the argumentation, that even when a road is elevated half a meter above the flooded ground, its basis may destabilise, as it has been proved to be a major problem for roads in previous floods [37]. Moreover, bridges cannot be used in a flood, when they still stand out of the water, but their access lanes are flooded, and the same is true for hospitals and other CI [6]. In the area shown in Figure 5, a fire brigade station was flooded by the stream flowing through the streets of Erftstadt-Blessem. Not being a CI, 
but of heritage value, a historic castle was partly affected, too. These analyses as well as the 2021 floods revealed a major gap not only in public data availability in Germany, but also in risk maps and related methodologies that do not include CI objects and their cascading effects, yet. However, this example of openly admitting shortcomings of scientific work is another challenge too. Not only in terms of discussing questions of shortcomings of analyses with the public or media. But it is a major challenge getting own shortcomings in methodology or results that are openly addressed being accepted by some in the scientific community, for example, in a journal review process. Therefore, it is again an important task in the future to increase acceptance and transparency not only for science-practice transfers of knowledge but also between scientists.

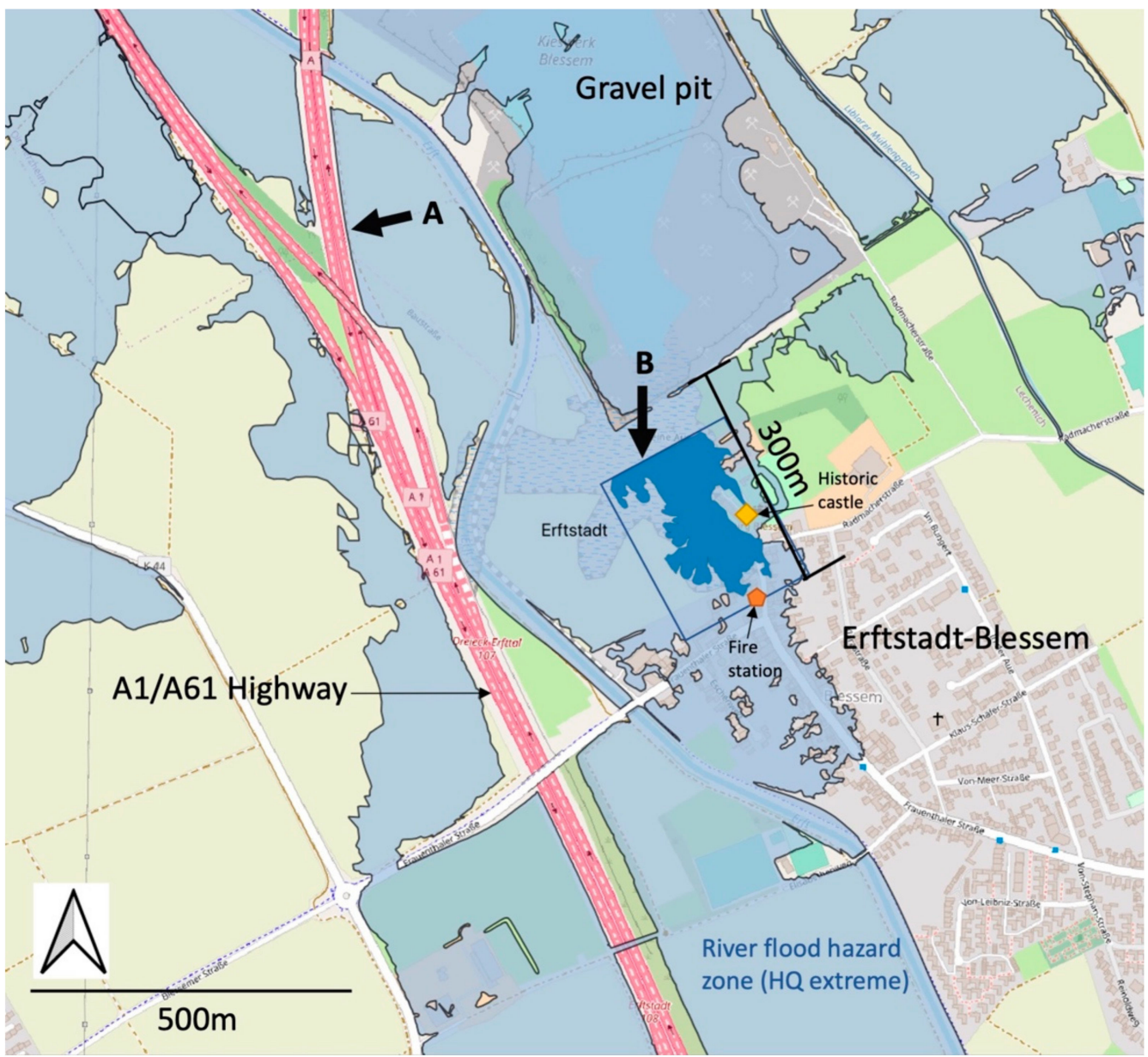

Figure 5. Riverine flood maps covering Erftstadt and the heavily flooded parts of Erftstadt-Blessem with an example of a mapping issue (A) and a backward erosion area caused by the floods (B).

\subsection{Decoding Compounding Events and Escalations in Social Cohesion}

The 2021 floods in Germany were events concurrent with an ongoing SarsCov2 pandemic situation and an ongoing background process of climate change. Recent research uses different terms for this, concurrent risks or crises [38,39], multi-hazard or risk [40,41], compounding events [42] or cascading effects [43]. Adding to this, a social escalation spiral amplified the risk [44] during the immediate aftermath of the flood. While volunteer helpers flocked into the disaster-affected areas, certain activist groups mingled in and tried to influence people or hinder official rescue teams, even violence was reported [45]. These activist groups formed under the protests against COVID-19 measures of the government, known as 'Querdenker' (German for lateral thinker). The online survey we conducted revealed that indeed misinformation from official sources $(32 \%)$ and from the media $(27 \%)$ 
was a major problem but some of the open answer text replies also explicitly mention these activist groups as a problem [26].

Obstruction and violence against first responders are on the rise in Germany [46], but the misinformation, uncertainty and activism in a natural hazard directed against the affected population as well as officials are quite another escalation step. While the activities of these groups could be contained in July/ August 2021, it raises major concerns about future disasters, where social unrest and violence could trigger severe secondary spirals of disaster, aggravating the already detrimental situations (Figure 6). The open replies of the respondents of the survey as well as the feedback in the focus group discussions support the media reports about hinderance and misinformation by those protest groups. The predominant group 'Querdenker' has been named explicitly in the open replies.

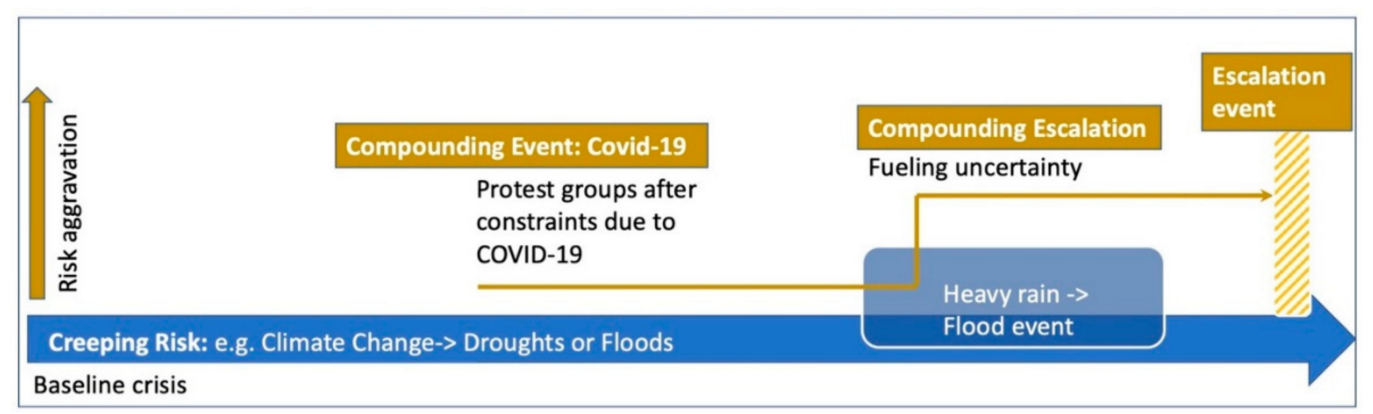

Figure 6. Social compounding event due to COVID-19 upon an ongoing flood situation.

German society currently still rests upon a highly democratic and also rather scienceinformed decision-making that heavily relies on an organised volunteer's system of more than 2 million people. Counter-democratic forces such as political right-wing groups that undermine public protests and lure frustrated people from all social milieus to frame under a protest movement, officially against COVID-19 measures, are a warning sign that society may have a bigger problem in a disaster stemming from the fragility of society itself, rather than from a given external hazard.

This would call for a more general understanding of a societal resilience culture to include social stability next to a focus on a specific hazard only [47]. Moreover, the root causes of societies [48] play out in industrialised as much as in developing country contexts. Hence, this example of societal escalations also needs to be investigated on communication culture. It is a major task to train a society not to ask for blame and fault, but rather, to accept uncertainty and ambiguity of information [49] and its interpretations. This is a difficult task, since many people, especially when overwhelmed by events such as unexpected disasters, first of all, long for simplified information they can immediately use. This should, however, not lead to an oversimplification only, but instead, ambiguities need also to be communicated, as well as unwelcome messages.

While the CIRmin project was concluded prior to COVID risks from lacking social cohesion and overburdening of rescue services due to high expectations or compounding events were already raised by experts at that time [50,51]. Societal change, such as an aging society with need for care and support, coupled with the growing dependency on power and other infrastructures to upkeep health services-a lesson that COVID-19 then made clear in an impressive way-was found lacking consideration in resilience strategies [52]. Expert interviews with representatives from fire brigades, technical relief, health services and public authorities shared the concerns over from decompounding events, such as impacts from power outages on drinking water supply, coupled with depleting individual preparedness [53]. The flood has proven these concerns to be true.

\subsection{Compounding Escalations due to Critical Infrastructure Failure}

The floods 2021 revealed a major weakness of modern societies; not only had the rains and floods affected people and properties directly, but the disaster was also aggravated by infrastructure failure or impairments. Early warning chains failed, due to numerous 
reasons, one major factor being the dependency of all systems on electricity; digital broadcasting, mobile phone and radio stations, etc. Access and evacuation were hampered by roads washed away, over 62 bridges were completely destroyed in the Ahr Valley alone [54]. Gas, water, sewage, food supply, shops of any kind and much more went away. Some infrastructure such as heating is expected to take months for reconstructions, making it unlikely to have heating in winter, still. The online survey showed that for over $52 \%$ of the operational teams, road failure was hindering their operations. 39\% claimed that failure of communication lines and 38\% stated that failure of digital radio were problems [26]. The household survey carried out in the CIRmin project revealed that out of the 1308 households asked, only around $50 \%$ possessed a radio that would work under power outage [51] showing that the problem does not only exist in this event, or for professional working with their digital radio equipment, but for communicating with the population, too. Under CIRMin, also scenarios such as long-lasting power cuts or water supply failure were analysed and conceptualised. As with the extreme events in the risk maps above, such scenarios often were facing scepticism whether they could really happen. Unfortunately, the 2021 floods proved many of them right, even in combination, and some emergency operational forces reported that actually, all CI was lost in some affected communities (oral.com accessed on 4 August 2021, anonymised).

One ambition of the CIRmin project was to establish a CI resilience concept that would narrow down the broad topic by focusing on a minimal supply situation. This situation is defined to be below optimal daily situations, and even below degraded supply (Figure 7). A minimum supply situation means that not only some infrastructure fails and that not all people can be supplied anymore, but it also means that the focus must shift towards preserving certain vital infrastructure to enable a restart. Typically, many electronic systems would go into standby mode in such a situation, automatic backups are written, other resources are cut to minimum consumption and only a few selected services are kept operating. The same is the case with all capabilities of emergency management; in the everyday case, emergencies, even deaths occur, but they can be managed based on the established system, its resources, framing and culture. There are fluctuations, there are some better and worse days, but this is within a certain corridor of known and expected emergencies (Figure 7).

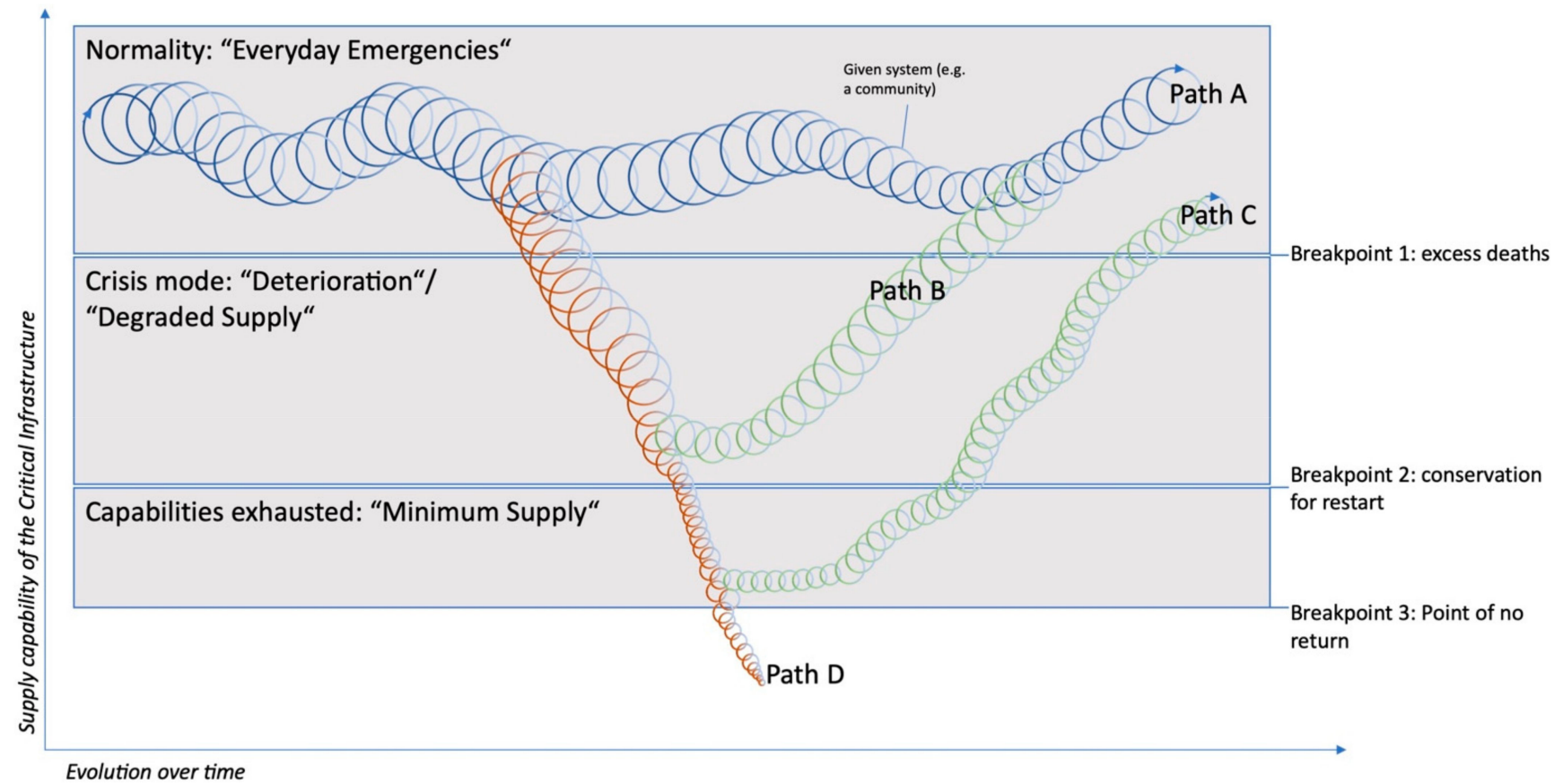

Figure 7. Corridors of emergency management and its capability to take care of a community (or other given system), deterioration, downward spiralling and recovery pathways. 
But some crises or disasters put additional stress and components of unknown situations on emergency management and disaster relief teams. The capability of the affected system to protect (the community) and its capabilities are strained and can deteriorate (Figure 7). That downward spiral is composed of multiple components; the capabilities of the people, their resources, motivation and many more. It is difficult to determine a threshold, but excess deaths, that is more deaths than usually occur in daily emergency management for a given hazard, could be an indicator or such a breaking point 1 (Figure 7). It is important to better recognise, how much these capabilities are dependent on baseline infrastructure services. The next phase or corridor is the crisis mode, as depicted in Figure 7. This is the phase where many systems are not fully operational anymore but operate in a degraded mode. More deaths and losses are likely, and the affected system can dwindle even more, or recover (Path B). In triage, this would be the category not to save all people anymore, but most people.

It is difficult to determine a threshold for when this situation gets significantly worse, but a breaking point 2 could be when more deaths and losses become unavoidable despite all efforts, and capabilities have to be concentrated and reduced to save what is left alive or operational. After a phase of a standby mode, CI systems should be kept stationary or running on redundancies, that typically are not designed to fully replace the original services. There is a path to recovery after a while for the population and CI systems left, when being able to rebuild and restart. There still, however, is a breakpoint 3, when the system and its capabilities further deteriorate, and the given community and its supporting services cannot be restored (Path D).

At the example of the 2021 floods, and based on the survey and expert interviews, some areas have been destroyed so heavily that all CI was damaged to a point beyond repair, and they ceased operation. In the Ahr valley, this included roads, rail, bridges, electricity, cell broadcast, food, water, sewage, hospitals and many more of the CI. Some interviewees claimed, all CI were dysfunctional. In those areas, the communities had no functional $\mathrm{CI}$ to support them anymore and were fully reliant on external help and supply. This CI supply challenge is ongoing and will last over winter for utilities such as heating. This is an example for path $\mathrm{D}$, where the communities affected also have lost lives due to the floods, but also due to $\mathrm{CI}$ failure. These communities have to make decisions that are still under debate, whether to rebuild houses and certain CI or to shift settlement areas. One example that came out of expert interviews with a local mayor on a field visit on 13 September is the consideration which of the over 60 bridges to rebuild in the Ahr valley. On the one hand, many bridges have aggravated the flood damages by blocking debris and then collapsing, causing even higher flood peaks. On the other hand, the many often tiny bridges are necessary for the local farmers as well as for tourism, on which the region is dependent.

Most areas were affected partly, where some of the CI were destroyed, others were still operational, at least for a given time. Local capabilities became exhausted, and even external help could only support basic functions such as light, electricity, water and even lifesaving by helicopters only for a couple of hours per day. This phase of 'minimum supply' affected most of the areas hit hard at least during the ongoing pluvial flooding and the immediate days after. It is characterised by a reduction of operations to focus on the most important operations first; save lives, restore access for search and rescue etc. A pathway C can be achieved to return to a phase of degraded supply or even normality when a restart and restoration based on the minimum supply that has been retained is successful.

In other areas, such as Erftstadt, some CI were destroyed such as certain road segments and sewage, but access to the sites affected could still be rerouted and enabled while being degraded. While one local fire station was dysfunctional and cars damaged, other fire brigades nearby could reach most of the areas and take over. While this is a severe situation, after a while, operational forces can return to a state of regular operations, while not fully operational as before. This is an example of a phase of 'degraded supply'. Another example is households that are provided water but need to boil it before using it. Temporary bridges 
erected by the army or Technical Relief Agency (THW) with only one lane are another example. A pathway B can be achieved back to normality, when damages are repaired, and services restored.

Everyday emergencies continued to happen during the flood and fires had to be extinguished within areas not affected by the flood, for example. This led to a prioritisation of the operations in the flood-affected areas, and some residents were frustrated that no one helped them, as some comments in the survey reveal. From the perspective of the firefighters and rescue services, this was a normal state of operations, to allocate their specific resources only in declared priority areas; at the same time, keeping back some resources to continue being able to run everyday emergency operations such as house fires, too. This example shows that even during a disaster, different phases can co-exist; everyday operations that are running next to disaster response. It was also visible in some locations that certain neighbouring quarters of a city or village were flooded, whereas the next nearby streets were in a state of normality.

Many risk assessments struggle to estimate the possible risk of deaths and losses overall, and estimates are provided in wide ranges. Prioritisation methods can be helpful to get more detailed assessments, for example, which CI services are most critical to supporting all people in an everyday situation, in degraded mode or minimum supply mode [33]. This includes methods of identification of CI for a given community [55], including an evaluation of which societal target values are to be prioritised for different stakeholder and interest groups [56]. Vulnerability assessments can help to determine how organisational and technical aspects aggravate a system's fragility and downward spiral [57]. Resilience assessments still need further operationalisation, but they can provide inspirations on not only what breaks down, but how recovery paths can be identified and for example, flooded roads be navigated to enable a community to access hospitals or enable repair teams to access destroyed sites [58].

Overall, understanding the relation or rather, interdependency between affected communities, their capabilities for recovery but dependency on infrastructure is key for handling multi-risks. In addition, interdependencies between relief actors, their limited capabilities due to being affected from the same infrastructure impairments and resulting challenges for supporting communities need to be understood. At all stages, some breakpoints severely change the situation and $\mathrm{CI}$ is one major factor to buffer breaking points or to speed up the downward spiral after failure. But using concepts of different stages of disaster impact spirals can also help to better outline the recovery pathways (Figure 7).

\section{Lessons to Learn}

Selected lessons to learn derived from the CIRmin project in certain aspects become visible in the flood in July 2021 and are briefly summarised here, mainly to point out the key areas for further investigation. In addition, we have conducted focus group discussions, interviews with flood and disaster experts, civil protection, volunteer helpers and field visits with local administrations and people affected in August and September 2021, after the floods. Furthermore, the findings in this paper and our summary below (Figure 8) are supported by a recent online survey we have conducted with operational response forces and volunteer helpers [26]. The information from 2264 completed questionnaires includes motivation, information provision, cooperation, infrastructural failures, problems, risks and suggestions of improvements. The analyses of the survey are still ongoing since over 90 pages of written text have to be analysed, too. The question in the background of the analyses also is how to guide rebuilding, rehabilitation and transformation of a whole region that has experienced such widespread damage and loss. Another valid question is how to then mainstream the learning from this survey, and previous ones, into actual decision-making around recovery. 


\begin{tabular}{|c|c|c|}
\hline Sendai Framework priority area & $\begin{array}{l}\text { Gaps and challenges apparent } \\
\text { prior to the flood }\end{array}$ & $\begin{array}{l}\text { Gaps and challenges identified } \\
\text { during and after the flood }\end{array}$ \\
\hline $\begin{array}{l}\text { Priority 1: } \\
\text { Understanding disaster risk }\end{array}$ & $\begin{array}{l}\text { - Lack of familiarity with such events, disbelief in } \\
\text { their probability, both with responsible authorities } \\
\text { and individuals } \\
\text { - Largely non-existent inclusion of resilience in } \\
\text { risk concepts and assessments }\end{array}$ & $\begin{array}{l}\text { Disbelief in predicted flood levels, lack of timely } \\
\text { proclamation of a state of disaster in affected } \\
\text { communities }\end{array}$ \\
\hline $\begin{array}{l}\text { Priority } 2 \text { : } \\
\text { Strengthening disaster risk governance to } \\
\text { manage disaster risk }\end{array}$ & $\begin{array}{l}\text { False expectations of help and liability between } \\
\text { infrastructure operators, emergency relief, } \\
\text { organizations and other actors within and across } \\
\text { administrative levels } \\
\text { Lack of application of available guidance to } \\
\text { improve risk governance and preparedness }\end{array}$ & $\begin{array}{l}\text { - Authorities' difficulties in managing and } \\
\text { coordinating huge volume of voluntary helpers } \\
\text { (around } 70,000 \text { in Ahr Valley alone until Oct) } \\
\text { - Subsequent emergence of private-led } \\
\text { transportation and coordination activities of } \\
\text { voluntary helpers } \\
\text { - Partial dissatisfaction of affected people with } \\
\text { state-led support, e.g. of rescue organisations }\end{array}$ \\
\hline $\begin{array}{l}\text { Priority } 3 \text { : } \\
\text { Investing in disaster risk reduction for } \\
\text { resilience }\end{array}$ & $\begin{array}{l}\text { - Lack of investments in coherent early warning } \\
\text { systems including cell broadcast } \\
\text { Implementation of cell broadcast was found to } \\
\text { be unnecessary and costly (post-event } \\
\text { estimates range from } 20 \text { to } 40 \text { Million } € \text { ) } \\
\text { - Lack of private natural hazard insurance } \\
\text { covering flood damage (coverage of } 46 \% \text { on } \\
\text { average in Germany) }\end{array}$ & $\begin{array}{l}\text { - Political willingness to finance implementation of } \\
\text { cell broadcast without discussing link to other } \\
\text { early warning systems } \\
\text { - Potentially false incentives against private } \\
\text { precaution by state reconstruction funds } \\
\text { (emergency aid commitments of } 200 \text { million } € \\
\text { each from federal government and } \\
\text { Bundesländer) despite earlier political rejection }\end{array}$ \\
\hline $\begin{array}{l}\text { Priority 4: } \\
\text { Enhancing disaster preparedness for effective } \\
\text { response, and to "Build Back Better" in } \\
\text { recovery, rehabilitation and reconstruction }\end{array}$ & $\begin{array}{l}\text { Major expectation of people to receive state } \\
\text { support during and after disaster events } \\
\text { - Largely unquestioned reliance on functioning } \\
\text { infrastructure supplies } \\
\text { - Lack of flood protection plans for smaller } \\
\text { streams }\end{array}$ & $\begin{array}{l}\text { - Underestimated dependency on (other) critical } \\
\text { infrastructures, e.g. communication and power } \\
\text { - Month- to year-long recovery phase e.g. of fuel } \\
\text { supply, road and railroad constructions } \\
\text { - Underestimation of consequences of lacking } \\
\text { - } \quad \text { ocial infrastructure like nurseries } \\
\text { - Destruction of gauges at smaller streams }\end{array}$ \\
\hline
\end{tabular}

Figure 8. Lesson to learn gaps and challenges prior, during and after the flood 2021. Sources of the content: [20,59-61].

Comparable surveys had been conducted on previous flood events in Germany on similar topics of flood damages and perceptions of risk of households with comparable sample sizes, such as for the floods in 2002 with $\mathrm{N}=910$ and in 2013 with $\mathrm{N}=1652$ [62]. Several surveys focus on recovery $[62,63]$, some on the health and psychological aspects of those affected [64]. Many studies are cross-sectional while longitudinal studies are still rare [62,65]. Some studies focus on volunteer helpers and the topic of their integration $[66,67]$. Studies involving first responders are still rare, some use focus group discussions as in our study, but find gaps concerning their inclusion into scientific studies [65]. This gap justifies our target group and survey approach. In addition, we have initiated and set up a forum to gather data from all ongoing research projects in Germany after the flood event in July to be able to a) compare the data and b) make it transparent and enable access by other fellow researchers as well as the interviewees and the public. It is based at a recognised nonprofit organisation in Germany (http: / / www.dkkv.org, accessed on 25 October 2021) [68] and as soon as the ongoing surveys will be completed and published, a comparison will be possible.

All four priorities of the Sendai Framework [69] were relevant, also in this disaster, as a bitter lesson; there still is a major demand for knowing more about risk, especially amongst the breadth of society unfamiliar with such situations, despite all media coverage of similar disasters worldwide on an almost weekly scale. This is also true for many other actor groups such as decision-makers. As in other disasters, it does not help that this event had antecedent events. Directly neighbouring regions such as Bonn, Wachtberg, had received severe damages due to heavy rains in 2010 and 2016 [70]. The Federal Office of Civil Protection and Disaster Relief (BBK) had run a major research project afterwards and published guiding manuals for homeowners to retrofit their houses, amongst other measures. Still, for the national public, such events were widely unimaginable, and for sure, the death toll in 2021 is higher than in any other natural hazard event since the storm surge at Hamburg in 1962. The death toll is much higher than in the river-floods of 2002, too, for example. But it is not due to the high amount of rain, since Münster city (some $100 \mathrm{~km}$ away from the flood-affected areas) had seen $292 \mathrm{~L} / \mathrm{m}^{2}$ within $7 \mathrm{~h}$ in 2014 [71]. Some areas such as the Ahr valley also had seen similar destruction of all bridges collapsed due to floods in 1804 or 1910 [72]. However, it is important to point out that it is not possible 
to directly compare the impacts of similar precipitation events in different centuries. The land use and infrastructure has significantly changed over decades, and so has societal dependency on CI. For example, the built infrastructure has narrowed the river beds, and soil sealing has reduced infiltration rates [72].

The other three Sendai Framework priorities also reveal gaps in this event of 2021: it became evident that it is important still, to foster the strengthening of institutions, motivating economy and better planning of reconstruction and rehabilitation ('build back better'). CI, a theme that became pointed out in the Sendai Framework first time that prominently (as one of seven targets), is just one of many important disaster impact categories, after mortality and health, for example. But infrastructure also is a key to the resilience abilities of affected people and relief forces alike. When electricity, information flows, drinking water, hospitals and rescue teams are dysfunctional, a disaster further spirals to the negative. Therefore, the CIRmin project focused on infrastructure, and hence, the following lessons to learn focus on this topic (Figure 8). Not only the CIRmin project results but also focus group discussions we have conducted after the flood with operational forces, volunteer helpers, flood experts from administration and research and affected people from field visits provide the information for our findings in this paper and our summary of it in Figure 8.

Before a disaster, knowledge about risks and resilience needs to be fostered. For example, by informing people: Getting people interested in disasters is a known problem and fully understandable since there are many more important and urgent topics on the minds of people in everyday life. In Germany, this is especially the case since major catastrophic events are rare, and people got accustomed to work-sharing, and existing institutions that are responsible for daily rescue and emergencies. The vulnerability paradox helps to explain that society has become developed to such an extent, that shocks take people more by surprise and hence, make them more vulnerable due to their dependency on a functioning system [73]. Therefore, the topic of CI, scenarios of power blackouts or cyber-attacks are among the main scenarios for civil protection planning in Germany lately.

Although attention was paid to floods at the time of the study, but the following weeks soon brought up hailstorms, wildfires in the Mediterranean and elsewhere. It will remain a challenge to broadly get people informed about risks in a sense they will be able to know what to do themselves and not relying on other institutions to deal with it.

Household surveys in the CIRmin project revealed a major expectation of people in Rhein-Erft Kreis and Cologne that someone else would be responsible to help them $[50,53]$. This pattern differs between groups of people and families and elderly citizens were more likely to identify themselves as being responsible or ready to prepare for a blackout or water outage than young singles, students or others.

Informing institutions about risks is an important topic and since institutions have such a prominent role in Germany, there are major leverages to foster disaster risk governance. Hence, risk analyses, risk maps, risk indicators and many other forms are important to reanalyse regarding their usefulness, completeness of methodology and rooms for improvement. In comparison to the CIRmin project findings, the following recommendations for further improvement can be deducted:

Awareness gaps:

- People are overly dependent on public institutions to help them. Not only self-help needs to be better promoted and guided, but people also need to better understand what type of help not to expect. Frustrations of people who have lost their homes on operational relief forces just drive by their ruins are one example. People need to understand that fire brigades, for example, first need to help other priority areas and are not intended to clean out the debris from home.

- Operational forces need to be trained to train lay people also about what type of help not to expect from them. The same applies to many actors, we found out in the CIRmin project; many neighbouring communities have never met at the working level, and false expectations of help and liability exist between infrastructure operators, 
emergency relief, people and others within the one and same community, and between neighbouring communities.

- $\quad$ Research in the field of disaster preparedness and CI is still often siloed and technologyfocussed. Despite promising approaches through targeted research funds and transdisciplinary projects, holistic approaches with a direct link to practice and implementation are underdeveloped.

Assessment gaps:

- Identification of priority infrastructure and backup solutions for a minimum supply. A guiding concept manual of the Federal Office BBK exists [55] but is not yet applied by communities, except for very few.

- Identification of priority groups of vulnerable people at risk in specific critical infrastructure facilities such as health care, but also in general.

- Holistic concepts including resilience are largely non-existent. Many analyses or risk information just cover flood hazard or risk maps, but no demand planning for capacities, resources or specifically for CI or vulnerable people.

- Not fostering all attention now on a heavy rain floods scenario, but rather on multi-risk assessments of risk and capacities.

Construction

- $\quad$ Early warning systems are part of CI. They are just as dependent on power and roads to access them for repair as many other CI. Key features of resilience such as redundancies must be kept or created; when one communication system fails, another one must function, at least one or the other. The $n-1$ principle hence must also consider different modalities of one service; when digital broadcast communication fails, analogous radio needs to be maintained. Door-to-door warnings, as well as paper and pencil, are important means of communication, still.

- Many communities were lacking assessments and guidance for solutions on how to build redundancies or other means of improving their capacities to deal with multiple types of events, before the flood. Construction of the main IT server in the basement of the stationary crisis centre needs to be avoided. Assessments and plans are not enough, resources and justification to start implementation, to spend budgets, must be granted for better construction.

Response phase:

- $\quad$ Routing and navigation through flooded roads and identifying alternative access routes proved to be a challenge. While examples of routing analyses have been conducted in the CIRmin project, this was only done for Cologne city and needs to be conducted for other areas, too. It also needs to be available for live routing.

- $\quad$ Regaining quick access to damaged houses, mobile phone ground stations, hospitals and all other CI by repair and relief teams is an important capability and existing capacity modules of technical relief agencies as well as of private operators need to be improved.

- Especially vulnerable populations need to be rescued. In a care home of mobility disabled persons, 12 died in the basement [74].

- One specific topic came up in the phase of identifying the failure of institutions and whom to blame. The warning chains were a prominent bone of contention, and people expressed frustration about not having received warnings or, not understanding that heavy rain warnings in the news meant they really needed to evacuate their houses. Repeating warnings, ensuring trustworthiness, making sure people are reached even when electric systems and mobile phones fail, all that needs to be added to a warning chain. The last mile of evacuation also needs to be developed in Germany.

- During the response and recovery, people need to be explained what help to expect and what not to expect.

Post-disaster phase: 
- To avoid false rebuilding construction type or at locations that are prone to the next flooding, multiple people in authorities need to 'sell the bad message' soon, despite the anger and frustration to expect. Build back better is easier said than done facing people who just have lost all they had. Recreating their identity is often connected with what is a 'home'. But to avoid experiencing the same destruction again in just a matter of weeks or years is important, too. While floating homes and protective walls are a means in low-lying areas, hilly areas need different approaches.

- Helpers need access to disaster sites. In the narrow Ahr valley, public access over the already partly destroyed roads was prohibited to enable access by the official relief forces. A private entrepreneur who just had lost his own premises, organised a bus shuttle transfer, operating for weeks when public authorities created no similar alternative (http:/ / www.helfer-shuttle.de (accessed on 4 September 2021)).

- Helpers also need to know about the risk of being wounded when working at disaster sites to clear out debris, pumping out basements. This must not lead to even more bureaucracy; no additional work safety drills for disaster helpers. But information apps on the bus shuttle could offer this as a voluntary service, not as an obligation.

- Availability of health gear, COVID-19 protection or else needs to be available for helpers and relief forces.

- Loss and damage assessments need to be carried out immediately, despite the sensitivity of the topic. Not just by the insurance companies, since they do not share their data.

- A bitter lesson, false communication, fake news, actions against the relief forces, false rumours all occurred in the aftermath. Some groupings of people united by anti-COVID-19 restrictions or similar, tried to interfere with public relief activities, misinformed affected residents, and some looting attempts also occurred [45]. It seems that public transparency about the activities of such groups is important and that such activities must be countered by official and professional communication and measures.

\section{Conclusions}

The main and most immediate problems identified in the 2021 flood disaster by operational forces and volunteer helpers as recorded here are awareness, assessment and construction as well as planning gaps that became evident in the disaster response in Germany. Next to these, the response and recovery phase will provide important lessons to learn and must be further investigated over the next months and years. However, the 2021 flood laid open gaps and constraints in German capabilities to anticipate, cope with and recover from such disasters that were already known from previous events and studies. The disaster scale has exposed them ruthlessly.

Four key areas were presented that provide additional lessons to learn and incentives at a more general and conceptual level, for a wider range of hazards and impacts. One key problem area is persisting knowledge interpretation and communication gaps. A key recommendation would be not putting blame on anyone, but decoding communication instead which can help to better understand diverging and ambiguous information and interpretations, for example, of the criticised early warning. Another long-known constraint in Germany is data and data exchange gaps between actors. A recommendation would be to point out the weakness in Germany regarding open data policies instead of looking only for mistakes of single authorities or levels. Simply looking for a scapegoat would be too easy and would not solve the real problem, but it seems to be happening at the moment.

Data sharing between institutions and to the public and 'digital twins' (data models and backups of the region) could be the first solution to speed up risk assessments. However, this is easier said than done, as the exchange between the federal government and the Bundesländer is often not unproblematic. The will to improve was often expressed after the flood, but it must be put into practice now. 
Other conceptual areas for improvement are related to decoding compounding events and escalations in social cohesion, and, compounding escalations due to critical infrastructure failure. Suggestions for improvement include a greater awareness even within the research community, more detailed concepts regarding the combination of hazard and impact chains, spirals and stages of deterioration, accompanied with a minimum supply concept to guide pathways to foster resilience and recovery.

Such conceptual insights are to generate more tolerance to ambiguous information from science for the public and other institutions, too. Disaster researchers are more familiar with hazards and risks, and it is normal that the general population is less so. It is comprehendible hence, that questions of guilt and liability arise to solve the lingering questions on how it came to be such a disaster. Lessons to learn are to be done by all sides, and scientists should take a lead, also openly expressing what went wrong on their side. But on the other hand, scientists also need to be encouraged to express their insights freely and without fear of repression, even when the information is ambiguous. Furthermore, the flood is also a judgement call for scientists, their faculties and funding schemes to overcome disciplinary thinking for the sake of more holistic approaches.

Finally, for the public audience, the messages are difficult to accept; more such events are likely to happen due to climate change, building back on-site may not be the ideal choice, there is a necessity for self-organisation and the emergency and governance system is as much liable to failure as everyone else. The vulnerability paradox will continue, which means that the emergency system development will need to keep pace with an increasing dependency of a large number of societal activities on the functioning of critical and baseline infrastructure services. Moreover, not only are public services and people increasingly dependent on electricity, IT and emergency services, since everything become more and more interconnected, also, the expectations continue to rise while the detachment from being able to influence this interconnected system grows, too. That means that a disaster will remain what it is, a disaster, and not a preparable design scenario.

Author Contributions: Conceptualisation, A.F.; methodology, A.F. and S.S.; formal analysis, A.F. and S.S.; investigation, A.F. and S.S.; writing—original draft preparation, A.F.; writing—review and editing, A.F. and S.S.; visualisation, A.F. and S.S. All authors have read and agreed to the published version of the manuscript.

Funding: Parts of the article are based on the funding of the research project CIRmin: Critical Infrastructure Resilience as a Minimum Supply Concept, from 2016 to 2019, financed by the Federal Ministry of Education and Research (BMBF), Germany (Grant Numbers 13N13989; 13N13990).

Institutional Review Board Statement: Ethical review and approval were conducted during the focus group discussions in the pretests with national and international experts.

Informed Consent Statement: Informed consent was obtained from all subjects involved.

Data Availability Statement: The survey data and questionnaire can be found at: https://riskncrisis. wordpress.com/data/ (accessed on 26 October 2021).

Acknowledgments: We are very grateful to the colleagues and partners in the project CIRmin: Critical Infrastructure Resilience as a Minimum Supply Concept, from 2016 to 2019, financed by the Federal Ministry of Education and Research (BMBF), Germany (Grant Numbers 13N13989; 13N13990). We would also like to thank all the operational relief forces and volunteer helpers for their astounding work, motivation and readiness to share their experience with us.

Conflicts of Interest: The authors declare no conflict of interest. 


\section{References}

1. Kreienkamp, F.; Philip, S.Y.; Tradowsky, J.S.; Sarah, F.K.; Lorenz, P.; Arrighi, J.; Belleflamme, A.; Bettmann, T.; Caluwaerts, S.; Chanal, S.C.; et al. Rapid Attribution of Heavy Rainfall Events Leading to the Severe Flooding in Western Europe during July 2021; World Weather Attribution: 2021; p. 54. Available online: https:/ /www.worldweatherattribution.org/wp-content/ uploads/Scientific-report-Western-Europe-floods-2021-attribution.pdf (accessed on 4 September 2021).

2. Zeit, D. Rund 40.000 Menschen im Ahrtal von Hochwasser-Folgen Betroffen. Available online: https://www.zeit.de/gesellschaft/ 2021-07/hochwasser-rheinland-pfalz-ahrweiler-folgen-ueberschwemmung? (accessed on 15 October 2021).

3. Schäfer, A.; Mühr, B.; Daniell, J.; Ehret, U.; Ehmele, F.; Küpfer, K.; Brand, J.; Wisotzky, C.; Skapski, J.; Rentz, L. Hochwasser Mitteleuropa, Juli 2021 (Deutschland). 21. Juli 2021—Bericht Nr. 1 “Nordrhein-Westfalen \& Rheinland-Pfalz"; Center for Disaster Management and Risk Reduction Technology: 2021; p. 31. Available online: https://www.cedim.kit.edu/download/FDA_ HochwasserJuli2021_Bericht1.pdf (accessed on 4 September 2021).

4. Junghänel, T.; Bissolli, P.; Daßler, J.; Fleckenstein, R.; Imbery, F.; Janssen, W.; Kaspar, F.; Lengfeld, K.; Leppelt, T.; Rauthe, M.; et al. Hydro-klimatologische Einordnung der Stark- und Dauerniederschläge in Teilen Deutschlands im Zusammenhang mit dem Tiefdruckgebiet "Bernd" Vom 12. Bis 19. Juli 2021; DWD: Offenbach, Germany, 2021; p. 16.

5. Dierich, A.; Tzavella, K.; Setiadi, N.; Fekete, A.; Neisser, F. Enhanced Crisis-Preparation of Critical Infrastructures through a Participatory Qualitative-Quantitative Interdependency Analysis Approach. In Proceedings of the ISCRAM 2019 Conference, Valencia, Spain, 19-22 May 2019.

6. Fekete, A. Critical infrastructure cascading effects. Disaster resilience assessment for floods affecting city of Cologne and Rhein-Erft-Kreis. J. Flood Risk Manag. 2020, 13, e312600. [CrossRef]

7. Fekete, A.; Neisser, F.; Tzavella, K.; Hetkämper, C. (Eds.) Wege zu Einem Mindestversorgungskonzept. Kritische Infrastrukturen und Resilienz; TH Köln: Cologne, Germany, 2019; p. 106.

8. Albert, C.; Rufat, S.; Kuhlicke, C. Five principles for climate-resilient cities. Nat. Corresp. 2021, 596, d41586-d42021.

9. Kuhlicke, C.; Albert, C.; Bachmann, D.; Birkmann, J.; Borchardt, D.; Fekete, A.; Greiving, S.; Hartmann, T.; Hansjürgens, B.; Jüpner, R.; et al. Five Principles for Climate-Proof Municipalities and Cities; Leipzig, Germany, 2021; p. 10. Available online: https:/ / www.ufz.de/index.php?en=48382 (accessed on 4 September 2021).

10. Baumgartner, C.; Bentler, C.; Fekete, A. Studying extreme events from the perspective of the disaster relief workers involved in 2013 floods in Germany. In Recovery after Extreme Events. Lessons Learned and Remaining Challenges in Disaster Risk Reduction; Fekete, A., Garschagen, M., Norf, C., Stephan, C., Eds.; TH Köln: Köln, Germany, 2017; Volume 2, pp. 87-91.

11. Raphael, B. When Disaster Strikes. A Handbook for the Caring Professions; Century Hutchinson: London, UK, 1986.

12. Erikson, K.T. Loss of communality at Buffalo Creek. Am. J. Psychiatry 1976, 133, 302-304.

13. Mathiesen, K.; Von Der Burchard, H.; Gehrke, L. Over 100 Die in Germany, Belgium Floods Despite Early Warnings. Available online: https:/ / www.politico.eu/article/germany-floods-dozens-dead-despite-early-warnings/ (accessed on 4 September 2021).

14. EFAS. Frequently Asked Questions on EFAS and the Information EFAS Provided during the Flood Events Affecting the Rhine and Meuse River Basins. EFAS Flood Forecast from 12.07.2021 00:00 UTC. Available online: https://www.efas.eu/en/news/faqefas-and-recent-flood-events (accessed on 4 September 2021).

15. Mannheim, F.; Schenk, N. Wann Hat Wer Gewarnt?-Eine Rekonstruktion. Available online: https://www1.wdr.de/nachrichten/ landespolitik/chronologie-hochwasser-warnungen-100.html (accessed on 4 September 2021).

16. Völlnagel, I. Warum Kam die Warnung So Spät? Available online: https://www.tagesschau.de/inland/hochwasser-warnung-10 1.html (accessed on 4 September 2021).

17. Tagesschau. Ermittlungen Gegen Landrat von Ahrweiler. Available online: https://www.tagesschau.de/inland/ahrweiler-115. html (accessed on 4 September 2021).

18. tz. Hochwasser-Drama in NRW: Feuerwehrmann Ertrinkt bei Rettungsversuch-Kurz Darauf Stirbt Weitere Einsatzkraft. Available online: https://www.tz.de/welt/hochwasser-feuerwehrmann-tot-altena-unfall-ueberschwemmungen-nrw-nordrheinwestfalen-90861986.html (accessed on 16 July 2021).

19. Plück, M. Frontalangriff bei Flutaufarbeitung. NRW-Opposition Will Laschet, Landesminister und Experten im Untersuchungsausschuss Vernehmen. General-Anzeiger 9/10 October 2021. Available online: https://rp-online.de/nrw/ landespolitik/opposition-startet-frontalangriff-im-flut-untersuchungsausschuss_aid-63407081 (accessed on 4 September 2021).

20. Cornwall, W. Europe's deadly floods leave scientists stunned. Science 2021, 373, 372-373. [CrossRef]

21. Die Zeit. Bilder der Zerstörung und der Solidarität. Available online: https://www.zeit.de/wissen/umwelt/2021-07/ hochwasser-deutschland-fotos-ueberschwemmungen-sonntag (accessed on 4 September 2021).

22. FAZ. Landrat von Ahrweiler Beantragt Dauerhafte Dienstunfähigkeit. Available online: https://www.faz.net/aktuell/politik/ inland/ahrweiler-landrat-beantragt-dauerhafte-dienstunfaehigkeit-17525127.html (accessed on 11 September 2021).

23. GDV. Versicherungsschäden durch Flutkatastrophe bei Rund Sieben Milliarden Euro. Available online: https://www.gdv. de/de/medien/aktuell/versicherungsschaeden-durch-flutkatastrophe-bei-rund-sieben-milliarden-euro-69800 (accessed on 4 September 2021).

24. Deutscher Bundestag. Abstimmung über 30-Milliarden-Aufbaufonds für die Flutgebiete. Available online: https://www. bundestag.de/dokumente/textarchiv/2021/kw36-de-aufbauhilfe-857520 (accessed on 4 September 2021). 
25. Mohr, S.; Küpfer, K.; Wisotzky, C.; Ehmele, F.; Mühr, B. Hochwasser Mitteleuropa, Juli 2021 (Deutschland). Ergänzungen zum "Bericht Nr. 1 Nordrhein-Westfalen \& Rheinland-Pfalz"; Center for Disaster Management and Risk Reduction Technology: 2021; p. 7. Available online: https://www.dkkv.org/fileadmin/fonts/FDA_HochwasserJuli2021_Bericht1_Ergaenzungen.pdf (accessed on 4 September 2021).

26. Fekete, A. Vorläufige Erst-Auswertung zur Umfrage zur Zufriedenheit der Einsatzkräfte, Helferinnen und Helfer beim Hochwasser 2021; 2021; p. 22. Available online: https://www.dkkv.org/fileadmin/user_upload/Fekete_2021_Erste_Ergebnisse_ der_Hochwasser-Umfrage_2021.pdf (accessed on 4 September 2021).

27. Wannewitz, M.; Sandholz, S.; Garschagen, M. Kommunikation, Information und Medien. In Wege zu Einem Mindestversorgungskonzept. Kritische Infrastrukturen und Resilienz; Fekete, A., Neisser, F., Tzavella, K., Hetkämper, C., Eds.; TH Köln: Cologne, Germany, 2019; pp. 77-79.

28. Eco, U. A Theory of Semiotics; Indiana University Press: Bloomington, IN, USA, 1976.

29. Ogden, C.K.; Richards, I.A. The Meaning of Meaning: A Study of the Influence of Thought and of the Science of Symbolism; Harcourt, Brace \& World: New York, NY, USA, 1923.

30. Peirce, C.S. On a New List of Categories. Proc. Am. Acad. Arts Sci. USA 1868, 7, 287-298. [CrossRef]

31. Mileti, D.S.; Drabek, T.E.; Haas, J.E. Human Systems in Extreme Environments: A Sociological Perspective; Institute of Behavioral Science, University of Colorado: Boulder, CO, USA, 1975.

32. Edwards, C. Resilient Nation; Demos: London, UK, 2009.

33. Fekete, A. The CIRmin Project-Executive Summary. In Wege zu Einem Mindestversorgungskonzept. Kritische Infrastrukturen und Resilienz; Fekete, A., Neisser, F., Tzavella, K., Hetkämper, C., Eds.; TH Köln: Cologne, Germany, 2019; pp. 15-16.

34. Damm, M.; Fekete, A.; Uhlemann, S.; Zwenzner, H. Development of an Information System for Large-Scale Flood Events Supported by Remote Sensing (Project DISFLOOD). In Proceedings of the Beiträge zur Konferenz "Strategien und Instrumente zur Verbesserung des vorbeugenden Hochwasserschutzes", Tangermünde, Germany, 23-25 November 2005; pp. 133-141.

35. Fekete, A. Spatial disaster vulnerability and risk assessments: Challenges in their quality and acceptance. Nat. Hazards 2012, 61, 1161-1178. [CrossRef]

36. European Commission. Directive 2007/60/EC on the assessment and management of flood risks. Off. J. Eur. Union 2007, 27. Available online: https:/ / www.eea.europa.eu/policy-documents/directive-2007-60-ec-of (accessed on 4 September 2021).

37. Keller, S.; Atzl, A. Mapping Natural Hazard Impacts on Road Infrastructure-The Extreme Precipitation in Baden-Württemberg, Germany, June 2013. Int. J. Disaster. Risk Sci. 2014, 5, 227-241. [CrossRef]

38. Pappadà, R.; Durante, F.; Salvadori, G.; De Michele, C. Clustering of concurrent flood risks via Hazard Scenarios. Spat. Stat. 2018, 23, 124-142. [CrossRef]

39. Quigley, M.C.; Attanayake, J.; King, A.; Prideaux, F. A multi-hazards earth science perspective on the COVID-19 pandemic: The potential for concurrent and cascading crises. Environ. Syst. Decis. 2020, 40, 199-215. [CrossRef] [PubMed]

40. Granger, K.; Jones, T.G.; Leiba, M.; Scott, G. Community risk in Cairns: A multi-hazard risk assessment. Aust. J. Emerg. Manag. 1999, 14, 25-26.

41. Kappes, M.S.; Keiler, M.; von Elverfeldt, K.; Glade, T. Challenges of analyzing multi-hazard risk: A review. Nat. Hazards 2012, 64, 1925-1958. [CrossRef]

42. Zscheischler, J.; Westra, S.; van den Hurk, B.J.J.M.; Seneviratne, S.I.; Ward, P.J.; Pitman, A.; AghaKouchak, A.; Bresch, D.N.; Leonard, M.; Wahl, T.; et al. Future climate risk from compound events. Nat. Clim. Chang. 2018, 8, 469-477. [CrossRef]

43. Pescaroli, G.; Alexander, D. A definition of cascading disasters and cascading effects: Going beyond the â€ œtoppling dominosâ€ metaphor. Planet Risk 2015, 3, 58-67.

44. Kasperson, R.E.; Renn, O.; Slovic, P.; Brown, H.S.; Emel, J.; Goble, R.; Kasperson, J.X.; Ratick, S. The Social Amplification of Risk: A Conceptual Framework. Risk Anal. 1988, 8, 177-187. [CrossRef]

45. BR. Diebe, Gaffer, Querdenker: Viel Ärger in den Flutgebieten. Available online: https://www.br.de/nachrichten/deutschlandwelt/regierung-verurteilt-hochwasser-falschmeldungen-niedertraechtig,SeSk6XV (accessed on 4 September 2021).

46. Sefrin, P.; Händlmeyer, A.; Stadler, T.; Kast, W. Erfahrungen zur Gewalt gegen Rettungskräfte-aus der Sicht des DRK. Notarzt 2021, 37, S1-S19.

47. Jovanović, A.S.; Renn, O.; Schröter, R. Social Unrest; OECD Publishing: Paris, France, 2012.

48. Wisner, B.; Blaikie, P.; Cannon, T.; Davis, I. At Risk—Natural Hazards, People's Vulnerability and Disasters, 2nd ed.; Routledge: London, UK, 2004; p. 471.

49. Renn, O.; Klinke, A.; Van Asselt, M. Coping with complexity, uncertainty and ambiguity in risk governance: A synthesis. Ambio 2011, 40, 231-246. [CrossRef]

50. Stock, E.; Sandholz, S.; Lülf, M.; Fekete, A.; Dierich, A. Mindestversorgung zur Überbrückung von Ausfällen Kritischer Infrastrukturen. Wo wollen wir hin? In Proceedings of the Fachtagung Katastrophenvorsorge, Berlin, Germany, 28-29 October 2019; pp. 33-39.

51. Sandholz, S.; Sett, D.; Saenger, N. Ausfälle von Kritischen Infrastrukturen: Wie Resilient Ist die Bevölkerung? Bundesamt für Bevölkerungsschutz und Katastrophenhilfe (BBK): Bonn, Germany, 2020; pp. 32-35.

52. Sandholz, S.; Wannewitz, M.; Sabelfeld, R.; Garschagen, M. Versorgung einer sich ändernden Gesellschaft im Krisenfall: Neue und alte Akteure. In Wege zu Einem Mindestversorgungskonzept. Kritische Infrastrukturen und Resilienz; Fekete, A., Neisser, F., Tzavella, K., Hetkämper, C., Eds.; TH Köln: Cologne, Germany, 2019; pp. 74-76. 
53. Garschagen, M.; Sandholz, S.; Wannewitz, M. Verortung von Verantwortung für die Notfallversorgung bei Ausfällen. In Wege zu einem Mindestversorgungskonzept. Kritische Infrastrukturen und Resilienz; Fekete, A., Neisser, F., Tzavella, K., Hetkämper, C., Eds.; TH Köln: Cologne, Germany, 2019; pp. 32-33.

54. Staib, J. Ein Kolossales, Apokalyptisches Ausmaß. Available online: https://www.faz.net/aktuell/politik/inland/hochwasserin-rheinland-pfalz-roger-lewentz-zieht-erste-bilanz-17449104.html (accessed on 4 September 2021).

55. BBK. Schutz Kritischer Infrastrukturen-Identifizierung in Sieben Schritten. Arbeitshilfe fuür die Anwendung im Bevölkerungsschutz; Bevölkerungsschutz und Katastrophenhilfe (BBK): Bonn, Germany, 2017; p. 68.

56. Fekete, A. Common Criteria for the Assessment of Critical Infrastructures. Int. J. Disaster. Risk Sci. 2011, 2, 15-24. [CrossRef]

57. GFOCD (Ed.) Estimation of Vulnerability of Municipalities towards Floods (Abschätzung der Verwundbarkeit Gegenüber Hochwasserereignissen auf Kommunaler Ebene); Federal Office for Civil Protection and Disaster Assistance: Bonn, Germany, 2010; Volume 4, p. 195.

58. Tzavella, K.; Fekete, A.; Fiedrich, F. Opportunities provided by geographic information systems and volunteered geographic information for a timely emergency response during flood events in Cologne, Germany. Nat. Hazards 2018, 91, 29-57. [CrossRef]

59. Bundeszentrale für Politische Bildung. Jahrhunderthochwasser 2021 in Deutschland. Available online: https://www.bpb.de/ politik/hintergrund-aktuell/337277/jahrhunderthochwasser-2021-in-deutschland (accessed on 18 October 2021).

60. Stern. Cell Broadcast: Die Warn—SMS an Alle Wird in Deutschland Nicht Unterstützt—Warum? Available online: https: / / www.stern.de/digital/smartphones / cell-broadcasting--die-warn-sms-an-alle-wird-in-deutschland-nicht-unterstuetzt--warum--30625600.html (accessed on 18 October 2021).

61. SWR. Viele Tausend Helfer im Ahrtal—Doch Zahlen Sinken vor dem Winter. Available online: https://www.swr.de/swraktuell/ rheinland-pfalz/koblenz/helfer-flut-vor-dem-winter-100.html (accessed on 18 October 2021).

62. Thieken, A.H.; Bessel, T.; Kienzler, S.; Kreibich, H.; Müller, M.; Pisi, S.; Schröter, K. The flood of June 2013 in Germany: How much do we know about its impacts. Nat. Hazards Earth Syst. Sci 2016, 16, 1519-1540. [CrossRef]

63. Bubeck, P.; Thieken, A.H. What helps people recover from floods? Insights from a survey among flood-affected residents in Germany. Reg. Environ. Chang. 2018, 18, 287-296. [CrossRef]

64. Kuhlicke, C.; Masson, T.; Kienzler, S.; Sieg, T.; Thieken, A.H.; Kreibich, H. Multiple flood experiences and social resilience: Findings from three surveys on households and companies exposed to the 2013 flood in Germany. Weather. Clim. Soc. 2020, 12, 63-88. [CrossRef]

65. Hudson, P.; Thieken, A.H.; Bubeck, P. The challenges of longitudinal surveys in the flood risk domain. J. Risk Res. 2020, 23, 642-663. [CrossRef]

66. Hälterlein, J.; Madsen, L.; Schuchardt, A.; Peperhove, R.; Gerhold, L. Integrating volunteers in emergency response: A strategy for increased resilience within German Civil Security Research. In Urban Disaster Resilience and Security; Springer: Berlin/Heidelberg, Germany, 2018; pp. 113-128.

67. Poser, K.; Dransch, D. Volunteered geographic information for disaster management with application to rapid flood damage estimation. Geomatica 2010, 64, 89-98.

68. DKKV. Flutkatastrophe 7/2021. Aktuelle Forschungsaktivitäten. Available online: https://www.dkkv.org/de/navigationsmenue/ flutkatastrophe-07/2021/aktuelle-forschungsaktivitaeten (accessed on 20 October 2021).

69. United Nations. Sendai Framework for Disaster Risk Reduction 2015-2030; United Nations Office for Disaster Risk Reduction: Geneva, Switzerland, 2015.

70. Wachtberg, G. Unwetterschäden in Wachtberg. Available online: https://www.wachtberg.de/cms127/s/a/mr/a/2016-06-05 _starkregen_schaeden.shtml (accessed on 4 September 2021).

71. Münster, S. Bilanz zum Jahrestag des Ausnahme-Unwetters. Available online: https://www.muenster.de/stadt/unwetter-bilanz html (accessed on 4 September 2021).

72. Seel, K.A. Die Ahr und ihre Hochwässer in Alten Quellen. Available online: https://www.kreis-ahrweiler.de/kvar/VT/hjb1983/ hjb1983.25.htm (accessed on 4 September 2021).

73. NOTA—Rathenau-Instituut. Stroomloos: Kwetsbaarheid van de Samenleving, Gevolgen van Verstoringen van de Elektriciteitsvoorziening (Blackout. Vulnerability of Society and Impacts of Electricity Supply Failure); Rathenau Instituut: Den Haag, The Netherlands, 1994; p. 264.

74. ZDF. Zwölf Tote in Heim für Beeinträchtigte. Available online: https://www.zdf.de/nachrichten/panorama/hochwasserwohnheim-behinderung-tote-sinzig-100.html (accessed on 4 September 2021). 